Standard precaution knowledge and adherence: Do Doctors differ from Medical Laboratory Scientists?

\title{
Anne C. $\mathrm{Ndu}^{1}$, Sussan U. Arinze-Onyia ${ }^{2}$
}

1. Department of Community Medicine, University of Nigeria Nsukka

2. Department of Community Medicine, Enugu State University College of Medicine, Parklane Enugu

Background
Abstract
Doctors and laboratory scientists are at risk of infection from blood borne pathogens during routine
clinical duties. After over 20 years of standard precautions, health care workers knowledge and
compliance is not adequate.

Aim

This study is aimed at comparing adherence and knowledge of standard precautions (SP) among Medical Laboratory Scientists (MLSs) and doctors.

\section{Methods}

It was a cross sectional study done at University of Nigeria Teaching Hospital, ItukuOzalla. A semi structured pre-tested questionnaire was the study instrument.

Results

General knowledge of SP was high,76.2\% in doctors and 67.6\% in MLSs although there were differences between the two groups on the knowledge of components of SP. Safe injection practices, use of personal protective equipment as well as safe handling of contaminated equipment or surfaces was higher amongst doctors. Even though more than half of respondents in both groups, 53.1 $\%$ among doctors and 58.1\% among MLSs had received training on standard precautions, this did not reflect in the practice. MLS reported more use of personal protective equipment such as gloves and coveralls (100\% in MLS and 35\% of doctors), P<0.001. Recapping of syringes was higher amongst doctors (63.6\%) than MLS (55.1\%). The doctors practiced better hand hygiene than MLS $(\mathrm{P}<0.001)$. Constraints that affected SP included non-availability of PPEs and emergency situations for both groups.

\section{Conclusion}

SP knowledge and practice are still low, and as such, there is a need to train doctors and MLS on the components of SP. Policies on SP need to be enforced and facilities for practice regularly supplied.

\section{Introduction}

Careful adherence to standard precautions (SP) can protect health care workers and patients from infections. Health worker surveys and observations in Nigeria and Africa document that health workers often fail to practice standard precautions consistently and correctly ${ }^{1,2}$. Medical doctors and laboratory scientists are some of the health care workers that are significantly at risk of direct exposure to blood and other body fluids during the course of their normal clinical duties $^{3}$. Blood borne infections acquired during clinical and laboratory services have remained a major health issue worldwide, particularly in low income countries where there is high morbidity and mortality associated with such infections ${ }^{4}$. Some studies have shown that there is selective adherence and non-adherence to universal and standard precautions in daily medical practice and these differences in knowledge and adherence by health care workers may be influenced by their varying type of training ${ }^{5}$.

Standard precautions are a set of infection control practices used to prevent transmission of diseases that can be acquired by contact with blood, body fluid, and non-intact skin including rashes and mucous membranes. They are the basic level of infection control precautions which are to be used as a minimum in the care of all patients. The standard precautions emphasize the major features of universal precautions (designed to reduce the risk of pathogens from moist body substances) and apply them to all patients receiving care in hospitals regardless of their diagnosis or presumed infection status. Compliance with standard precautions has been shown to protect health care workers from different infections like human immunodeficiency virus, hepatitis $B$, hepatitis $C$ from sharps injuries and contact with body fluids ${ }^{6}$. WHO estimates that about $2.5 \%$ of HIV cases and $40 \%$ of Hepatitis B and C cases among health care workers are the result of these exposures?.

Standard precautions consist of: hand hygiene before and after every episode of patient contact, use of personal protective equipment, safe use and disposal of sharps, routine environmental cleaning, reprocessing of reusable medical equipment and instruments, respiratory hygiene and cough etiquette, aseptic non-touch technique, waste management and appropriate handling of linen ${ }^{6}$. Several hospitals have instituted standard precaution policies for all employees for all patients which include all the aspects of barrier use like hand washing, use of PPE like gloves, protective face and eye wear, gowns, protective apparel as well as patient placement and precautions when handling laboratory specimens.

Marcus et al reported that $37 \%$ of exposures to risks to blood borne infections might have been prevented if infection control precautions are adhered to and concluded that adherence to infection control precautions reduced exposure significantly ${ }^{8}$. several studies on knowledge and compliance to SP have been done in Nigeria but professional differences have not been established ${ }^{9,10}$.

This study was done to determine if the knowledge and adherence to standard precautions differ amongst these two groups of health workers. The study would help management to know the different aspects of standard precautions to emphasize for the different groups.

The study was descriptive cross-sectional done in October, 
Table 1: Socio - Demographic distribution of doctors

\begin{tabular}{|c|c|c|}
\hline & Doctors & Lab Scientists \\
\hline Demographic variables & $\begin{array}{c}\text { Frequency } \\
\mathrm{N}=143(100.0 \%)\end{array}$ & $\begin{array}{l}\text { Frequency } \\
\qquad \mathrm{N}=136\end{array}$ \\
\hline \multicolumn{3}{|l|}{ Gender } \\
\hline Male & $111(77.6)$ & $67(49.3)$ \\
\hline Female & $32(22.4)$ & $69(50.7)$ \\
\hline \multicolumn{3}{|c|}{$\chi^{2}=24.271 ;$ P Value $=<0.001$} \\
\hline \multicolumn{3}{|l|}{ Age range } \\
\hline $20-29$ & $27(18.9)$ & $32(23.5)$ \\
\hline $30-39$ & $62(43.4)$ & $46(33.8)$ \\
\hline $40-49$ & $33(23.1)$ & $44(32.4)$ \\
\hline $50-59$ & $21(14.6)$ & $14(10.3)$ \\
\hline \multicolumn{3}{|c|}{$\chi^{2}=; \mathrm{P}$ Value $=5.593 ; \mathrm{P}$ value $=0.133$} \\
\hline \multicolumn{3}{|l|}{ Marital Status } \\
\hline Married & $86(60.1)$ & $77(56.6)$ \\
\hline Single & $49(34.3)$ & $47(34.6)$ \\
\hline Widow/Widower & $6(4.2)$ & $9(6.6)$ \\
\hline Divorced/Separated & $2(1.4)$ & $3(2.2)$ \\
\hline \multicolumn{3}{|c|}{$\chi^{2}=; \mathrm{P}$ Value $=1.164 ; \mathrm{P}=0.762$} \\
\hline \multicolumn{3}{|l|}{ Religion } \\
\hline Christianity & $131(91.6)$ & $128(94.1)$ \\
\hline Islam & $6(4.2)$ & $6(4.4)$ \\
\hline African traditional religion & $6(4.2)$ & $2(1.5)$ \\
\hline \multicolumn{3}{|c|}{ Likelihood-ratio $\chi^{2}=1.952 ; \mathrm{P}$ Value $=0.377$} \\
\hline \multicolumn{3}{|l|}{ Location of work } \\
\hline ICU & $6(4.2)$ & $2(1.5)$ \\
\hline Theatre & $23(16.1)$ & $5(3.7)$ \\
\hline Ward & $39(27.3)$ & $7(5.1)$ \\
\hline Lab & $4(2.8)$ & $112(82.4)$ \\
\hline Casualty & $14(9.8)$ & $5(3.7)$ \\
\hline Outpatient dept. & $50(35.0)$ & $0(0.0)$ \\
\hline Blood bank & $1(0.7)$ & $5(3.7)$ \\
\hline Others & $6(4.2)$ & $0(0.0)$ \\
\hline \multicolumn{3}{|c|}{$\chi^{2}=199.264 ; \mathrm{P} ; \mathrm{P}$ Value $=<0.001$} \\
\hline \multicolumn{3}{|l|}{ Years of service } \\
\hline $1-5$ & $61(42.7)$ & $57(41.9)$ \\
\hline $6-10$ & $31(21.7)$ & $39(28.7)$ \\
\hline $11-15$ & $21(14.7)$ & $22(16.2)$ \\
\hline $16-20$ & $16(11.2)$ & $12(8.8)$ \\
\hline $21-25$ & $6(4.2)$ & $5(3.7)$ \\
\hline $26-30$ & $7(4.8)$ & $0(0.0)$ \\
\hline $31-35$ & $1(0.7)$ & $1(0.7)$ \\
\hline
\end{tabular}

Age range: 23 - 58 years; Years of service: 1 - 34 years

2014 among doctors and laboratory scientists at University of Nigeria Teaching Hospital (UNTH), Ituku-Ozalla, Enugu. These groups of HCWs are known to come in contact with hospital hazards. UNTH is located in Ituku Ozalla, a semihttp://dx.doi.org/10.4314/mmj.v29i4.3 urban community about 30 minutes - drive from the state capital. It is the biggest teaching hospital in the South east and South-south of Nigeria and gets referrals from most parts of these two regions. The departments studied were those ones that handle biohazards namely: Intensive Care Unit (ICU), Theatre, Wards, Laboratories, Casualty, Out-patient Department and Blood bank.

\section{Ethical Permit}

Ethical permission was obtained from the Ethics Committee of University of Nigeria Nsukka while informed consent was obtained from the management of University of Nigeria Teaching Hospital and the respondents.

\section{Data Collection}

The doctors and MLS who work in these departments were invited to be part of the study. Pre-tested selfadministered questionnaires were used to collect data from respondents. Contents of the questionnaire include demographical variables, knowledge and adherence to SP and associated factors.

\section{Data Analysis}

Data was entered and analyzed in Statistical Package for Social sciences (SPSS) version 17.

\section{Results}

One hundred and forty three doctors (77.6\% Males) and 136 MLS (49.3\% males) participated in the study. The age range was 23-58years for both groups. Majority $(65 \%$ of doctors and $70.6 \%$ of laboratory scientists) had between 1 and 10 years of service(Table 1$)$.

Most of the respondents $(93.7 \%$ of doctors and $96.3 \%$ of MLS) had heard of SP but only $76.2 \%$ of Doctors and $67.6 \%$ of MLS could correctly define SP (Table 2).

All the doctors $(100 \%)$ correctly identified the use of PPE compared to $76.5 \%$ of MLS. Similarly, Safe injection practices were correctly identified by $100 \%$ of doctors and $75 \%$ of MLS while identification of safe handling of contaminated equipment was done by $100 \%$ of the doctors and $79.4 \%$ of MLS. Knowledge of anal and peri-anal hygiene was poor among the MLS with only $16.9 \%$ compared to $76.2 \%$ in the doctors. Respiratory etiquette was only reported by $50.3 \%$ of doctors and $41.2 \%$ of the MLS. Almost $73 \%$ of doctors and $48.5 \%$ of MLS had knowledge of hand hygiene before aseptic procedures. On the other hand, $51.7 \%$ of doctors 
Table 2: Knowledge and Information on standard precaution

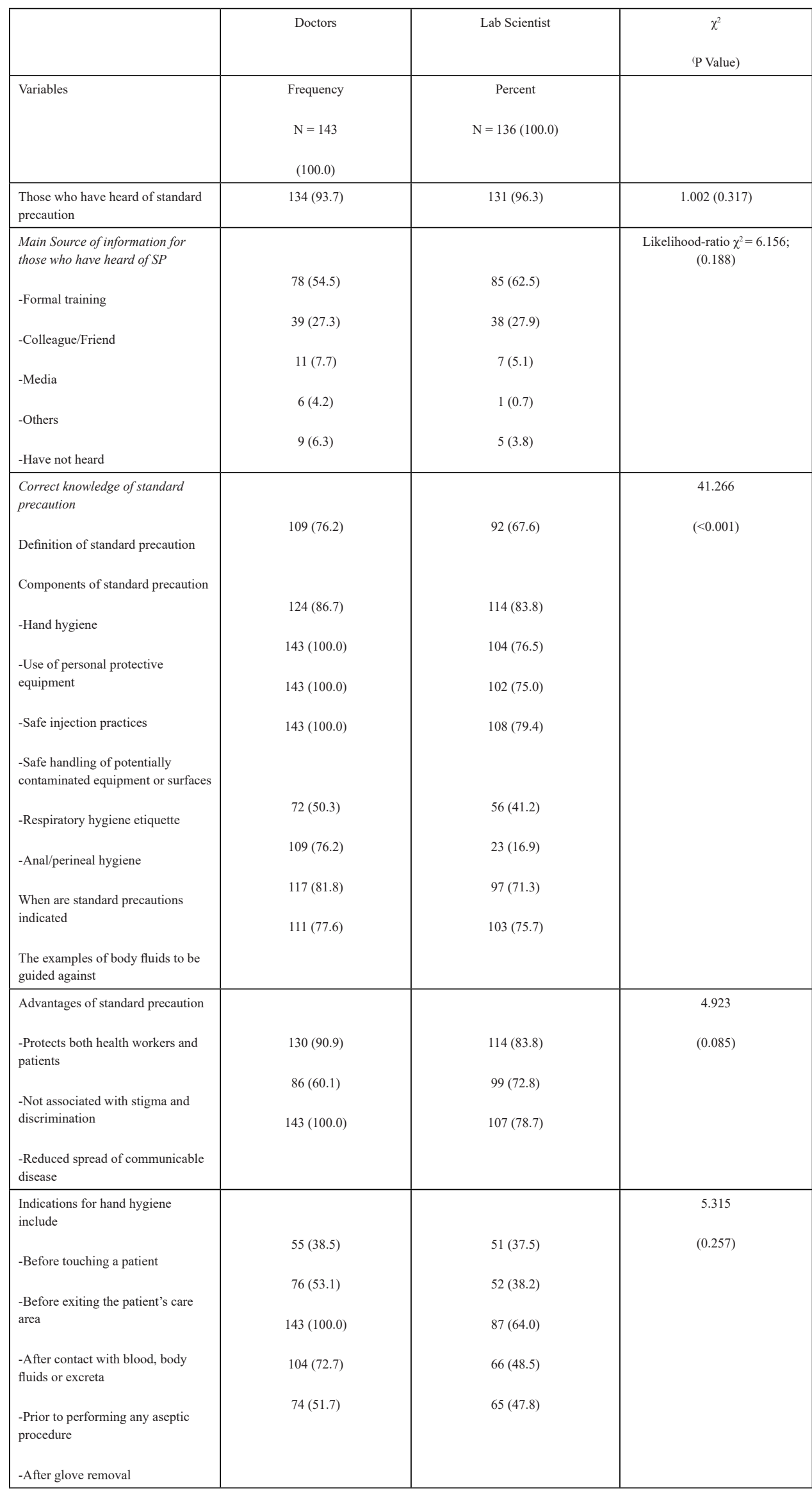

and $47.8 \%$ of MLSs knew about hand hygiene after glove removal. (Table 2). Only $12.6 \%$ of doctors and $19.1 \%$ of the MLSs reported knowledge of a hospital policy that enhances compliance to SP. There is however no formal hospital policy on standard precautions in the study area. (Table 3)

MLS reported perceived nosocomial infections more than the doctors $(20.6 \%$ and $13.3 \%$ respectively). Only about half (53.1\% of doctors and $58.1 \%$ of MLS) received any training on SP. Regarding availability of PPE $42 \%$ of doctors and $39.7 \%$ of MLS reported that PPE were sometimes available (Table 4).

There were little or no access to measures to limit respiratory infections $(21 \%$ doctors and $17.6 \%$ in MLS). Hand hygiene was significantly practiced more by doctors than MLS ( $43.2 \%$ for Doctors and 20\% for MLS, p $=0.001)$. Majority of both groups $(79.7 \%$ of doctors and $67.6 \%$ of MLS) have been exposed to patients' blood or body fluids during work. Use of PPEs (gloves and coveralls) was significantly higher amongst MLS (14.7\% for Doctors and $45.6 \%$ for MLS, $\mathrm{p}=0.001)$. Both groups $(63.3 \%$ doctors and $55.1 \%$ of MLS) still practice recapping of needles before discard. Management of an infected person was the major enabling situation that made both groups comply with SP $(74.1 \%$ and $72.1 \%$ ). Major constraint to use of SP identified by both groups was the non-availability of PPEs $(46.9 \%$ in doctors and $50.0 \%$ of MLS). Provision of PPE and regular training were suggested by both groups for improvement of compliance with SP.

\section{Discussion}

SP studies have revealed that health care workers have varying degrees of compliance ${ }^{10,11}$. This study has attempted to differentiate between the knowledge and practice among two health care professionals: doctors and MLS.

Despite the SP guidelines, knowledge and compliance vary among health workers and have been found to be inadequate in both developing and developed countries ${ }^{11}$. Despite reports of high knowledge in previous studies over several years in Nigeria, there has not been a reflection on the practice of $\mathrm{SP}^{12,3}$. Adherence to SP is poor in public health facilities in resource limited settings due to limited organizational support ${ }^{9}$. The knowledge of SP in our study was high amongst both groups $(93.7 \%$ in doctors and $96.3 \%$ in MLSs) as was also reported in other recent studies in Nigeria ${ }^{12,13}$.

Majority of the respondents could define SP properly. Similarly, a study in Northern Nigeria also found that $77.9 \%$ 
Table 3: Attitude of doctors and laboratory scientists to standard precautions

\begin{tabular}{|c|c|c|c|c|c|c|c|c|c|c|}
\hline \multirow[t]{2}{*}{ Attitude } & \multicolumn{2}{|c|}{$\begin{array}{c}\text { Strongly disagree } \\
(\%)\end{array}$} & \multicolumn{2}{|c|}{$\begin{array}{c}\text { Disagree } \\
(\%)\end{array}$} & \multicolumn{2}{|c|}{$\begin{array}{l}\text { Indifferent } \\
\qquad \%)\end{array}$} & \multicolumn{2}{|c|}{$\begin{array}{l}\text { Agree } \\
(\%)\end{array}$} & \multicolumn{2}{|r|}{$\begin{array}{l}\text { Strongly agree } \\
(\%)\end{array}$} \\
\hline & Drs & Lab Sci. & Drs & $\begin{array}{l}\text { Lab } \\
\text { Sci. }\end{array}$ & Drs & $\begin{array}{l}\text { Lab } \\
\text { Sci. }\end{array}$ & Drs & $\begin{array}{l}\text { Lab } \\
\text { Sci. }\end{array}$ & Drs & Lab Sci. \\
\hline $\begin{array}{l}\text { Do you agree that } \\
\text { employers should always } \\
\text { provide training on } \\
\text { Standard Precaution }\end{array}$ & $\begin{array}{c}0 \\
(0.0)\end{array}$ & $\begin{array}{c}0 \\
(0.0)\end{array}$ & $\begin{array}{c}0 \\
(0.0)\end{array}$ & $\begin{array}{c}0 \\
(0.0)\end{array}$ & $\begin{array}{c}2 \\
(1.4)\end{array}$ & $\begin{array}{c}6 \\
(4.4)\end{array}$ & $\begin{array}{c}41 \\
(28.7)\end{array}$ & $\begin{array}{c}40 \\
(29.4)\end{array}$ & $\begin{array}{l}100 \\
(69.9)\end{array}$ & $\begin{array}{c}90 \\
(66.2)\end{array}$ \\
\hline $\begin{array}{l}\text { Standard precautions are } \\
\text { useful in protecting against } \\
\text { hazards in workplace }\end{array}$ & $\begin{array}{c}4 \\
(2.8)\end{array}$ & $\begin{array}{c}0 \\
(0.0)\end{array}$ & $\begin{array}{c}0 \\
(0.0)\end{array}$ & $\begin{array}{c}0 \\
(0.0)\end{array}$ & $\begin{array}{l}3 \\
(2.1)\end{array}$ & $\begin{array}{c}3 \\
(2.2)\end{array}$ & $\begin{array}{r}41 \\
(28.7)\end{array}$ & $\begin{array}{c}47 \\
(34.6)\end{array}$ & $\begin{array}{l}95 \\
(66.4)\end{array}$ & $\begin{array}{c}86 \\
(63.2)\end{array}$ \\
\hline $\begin{array}{l}\text { Standard precautions are } \\
\text { not really necessary in } \\
\text { hospitals }\end{array}$ & $\begin{array}{c}93 \\
(65.0)\end{array}$ & $\begin{array}{c}71 \\
(52.2)\end{array}$ & $\begin{array}{c}44 \\
(30.8)\end{array}$ & $\begin{array}{r}49 \\
(36.0)\end{array}$ & $\begin{array}{l}3 \\
(2.1)\end{array}$ & $\begin{array}{c}14 \\
(10.3)\end{array}$ & $\begin{array}{c}1 \\
(0.7)\end{array}$ & $\begin{array}{c}1 \\
(0.7)\end{array}$ & $\begin{array}{c}2 \\
(1.4)\end{array}$ & $\begin{array}{c}1 \\
(0.7)\end{array}$ \\
\hline $\begin{array}{l}\text { Standard precautions are } \\
\text { meant only for theatre } \\
\text { workers }\end{array}$ & $\begin{array}{c}92 \\
(64.3)\end{array}$ & $\begin{array}{c}75 \\
(55.1)\end{array}$ & $\begin{array}{c}42 \\
(29.4)\end{array}$ & $\begin{array}{c}51 \\
(37.5)\end{array}$ & $\begin{array}{c}2 \\
(1.4)\end{array}$ & $\begin{array}{c}8 \\
(5.9)\end{array}$ & $\begin{array}{c}4 \\
(2.8)\end{array}$ & $\begin{array}{c}2 \\
(1.5)\end{array}$ & $\begin{array}{c}3 \\
(2.1)\end{array}$ & $\begin{array}{c}0 \\
(0.0)\end{array}$ \\
\hline
\end{tabular}

Table 4: Presence of Nosocomial Infection and Control measures provided by hospital management

\begin{tabular}{|c|c|c|c|}
\hline & Doctors & Lab Scientists & $\begin{array}{c}\chi^{2} \\
\text { (P Value) }\end{array}$ \\
\hline Variables & $\begin{array}{c}\text { Frequency } \\
\mathrm{N}=143(100.0 \%)\end{array}$ & $\begin{array}{l}\text { Frequency } \\
\mathrm{N}=136 \\
(100.0)\end{array}$ & \\
\hline $\begin{array}{l}\text { Presence of hospital } \\
\text { acquired infection among } \\
\text { workers since being } \\
\text { employed } \\
\text { No } \\
\text { Yes } \\
\text { Don't know }\end{array}$ & $\begin{array}{c}110(76.9) \\
19(13.3) \\
14(9.8)\end{array}$ & $\begin{array}{l}95(69.9) \\
28(20.6) \\
13(9.6)\end{array}$ & $\begin{array}{l}2.684 \\
(0.261)\end{array}$ \\
\hline $\begin{array}{l}\text { *Aware of hospital policy } \\
\text { that enhances compliance } \\
\text { to standard precaution }\end{array}$ & $18(12.6)$ & $26(19.1)$ & $2.238(0.135)$ \\
\hline $\begin{array}{l}\text { Received training on } \\
\text { standard precaution }\end{array}$ & $76(53.1)$ & $79(58.1)$ & $0.689(0.406)$ \\
\hline $\begin{array}{l}\text { Received training on } \\
\text { wearing or removing PPEs } \\
\text { (gloves, gowns, etc) }\end{array}$ & $21(14.7)$ & $100(73.5)$ & $\begin{array}{l}98.275 \\
(<0.001)\end{array}$ \\
\hline $\begin{array}{l}\text { Frequency of supply } \\
\text { of personal protective } \\
\text { equipment by hospital } \\
\text { Always } \\
\text { Sometimes } \\
\text { Never }\end{array}$ & $\begin{array}{c}79(55.2) \\
60(42.0) \\
4(2.8)\end{array}$ & $\begin{array}{c}78(57.3) \\
54(39.7) \\
4(3.0)\end{array}$ & $\begin{array}{l}0.147 \\
(0.929)\end{array}$ \\
\hline $\begin{array}{l}\text { Access to hand hygiene } \\
\text {-Always } \\
\text {-Sometimes } \\
\text {-Never }\end{array}$ & $\begin{array}{c}93(65.0) \\
49(34.3) \\
1(0.7) \\
\end{array}$ & $\begin{array}{c}75(55.2) \\
58(42.6) \\
3(2.2) \\
\end{array}$ & $\begin{array}{l}3.512 \\
(0.173)\end{array}$ \\
\hline $\begin{array}{l}\text { Measures put on ground } \\
\text { in the department to limit } \\
\text { spread of respiratory } \\
\text { infections } \\
\text {-None } \\
\text {-Signs at entrances with } \\
\text { instructions to cover } \\
\text { mouths and noses when } \\
\text { cough or sneezing } \\
\text {-Provide tissues and non } \\
\text { touch receptacles for } \\
\text { disposal of tissues } \\
\text {-Offer masks to coughing } \\
\text { patients } \\
\text {-Triage patients and ensure } \\
\text { that coughing patients are } \\
\text { among the first to be seen }\end{array}$ & $\begin{array}{l}30(21.0) \\
37(25.9) \\
48(33.6) \\
3(2.1) \\
25(17.5)\end{array}$ & $\begin{array}{c}24(17.6) \\
50(36.8) \\
35(25.7) \\
5(3.7) \\
22(16.2)\end{array}$ & $\begin{array}{l}5.164 \\
(0.271)\end{array}$ \\
\hline
\end{tabular}

*No known policy document in the study area. of health workers could define SP properly ${ }^{14}$. Concerning the components or elements of SP implying in depth knowledge of SP, Ogoina et al found that among professional groups, the median knowledge scores differed ${ }^{15}$. Similarly, another study reported that physicians were found to have insufficient knowledge of standard precautions ${ }^{16}$. In this study, doctors had significantly more knowledge. Knowledge on hand hygiene indications was low for both groups. This compared favorably with findings in Ilorin where only $56.7 \%$ of health workers knew of hand washing before and after patient care $^{10}$. Similarly, Ogoina reported that $58.5 \%, 28.1 \%$ and $63.6 \%$ washed after touching patients, after touching patients surrounding and after removing gloves respectively ${ }^{15}$. The level of knowledge concerning hand hygiene is surprisingly low considering recent epidemics of Ebola in West Africa and the public health education campaigns where hand hygiene is continually being emphasized. The practice of hand hygiene was equally poor due to inadequate access to hand hygiene resources. Similar poor access has been reported $^{17}$. Slightly above half of both groups reported to have received training on SP. A previous study in North Eastern Nigeria revealed that $55.2 \%$ of health workers received training from seminars and $27.6 \%$ from classroom lectures ${ }^{10}$. It would seem like SP is being taught formally in the MLS course content unlike for the doctors since their main source information was formal training. Other studies have reported that the main source of information was material taught during the curriculum, and nursing students were found to have a better mean overall score compared to medical students ${ }^{18}$. They concluded that knowledge levels were different by area and curriculum. Another study also reported their main source of information was selflearning and informal bedside practice $^{19}$.

The attitude to SP by both doctors and the MLSs was good. Both agreed that SP are useful to protect against hazards in the workplace, this is in agreement with other 
Table 5: Practice of Standard precaution by health workers

\begin{tabular}{|c|c|c|c|}
\hline & Doctors & Lab Scientists & $\begin{array}{c}\chi^{2} \\
\text { (P Value) }\end{array}$ \\
\hline Practice of standard precaution & $\begin{array}{r}\text { Frequency } \\
\mathrm{N}=143(100.0 \%)\end{array}$ & 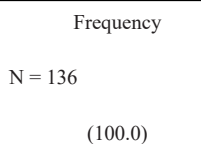 & \\
\hline $\begin{array}{l}\text { *When do you wash or decontaminate } \\
\text { your hands } \\
\text {-Before wearing gloves } \\
\text {-After removal of gloves } \\
\text {-Before touching a patient } \\
\text {-Before leaving a patient's care area } \\
\text {-Prior to performing an aseptic procedure }\end{array}$ & $\begin{array}{c}19(13.3) \\
51(35.7) \\
13(9.1) \\
83(58.0) \\
143(100.0)\end{array}$ & $\begin{array}{l}13(9.6) \\
71(52.2) \\
9(6.6) \\
34(25.0) \\
9(6.6)\end{array}$ & $\begin{array}{l}90.153 \\
(<0.001)\end{array}$ \\
\hline $\begin{array}{l}\text { Has your hand or other skin surface been } \\
\text { exposed to patient's blood or other body } \\
\text { fluids during work? } \\
\text {-Yes } \\
\text {-No/Can't remember }\end{array}$ & $\begin{array}{l}114(79.7) \\
29(20.3)\end{array}$ & $\begin{array}{l}92(67.6) \\
44(32.4)\end{array}$ & $\begin{array}{l}5.259 \\
(0.022)\end{array}$ \\
\hline $\begin{array}{l}\text { Action taken during the most recent contact } \\
\text { with patient's body fluid } \\
\text {-Nothing } \\
\text {-Washed off fluid with only water } \\
\text {-Washed off fluid with soap and water } \\
\text {-Washed off fluid with soap, water and } \\
\text { disinfectant } \\
\text {-Used only an alcohol-based hand sanitizer }\end{array}$ & $\begin{array}{c}\mathrm{N}=114(100.0) \\
4(3.5) \\
2(1.8) \\
42(36.8) \\
52(45.6) \\
14(12.3)\end{array}$ & $\begin{array}{l}\mathrm{N}=92 \\
(100.0) \\
0(0.0) \\
1(1.1) \\
23(25.0) \\
53(57.6) \\
\quad 15(16.3)\end{array}$ & $\begin{array}{l}\text { Likelihood-ration } \chi^{2} \\
=9.211 \\
(0.056)\end{array}$ \\
\hline $\begin{array}{l}\text { Personal protective equipments always } \\
\text { worn by health workers } \\
\text { when working } \\
\text {-Gloves or Coveralls } \\
\text {-Gloves only } \\
\text {-Gown only } \\
\text {-Gloves and coveralls }\end{array}$ & $\begin{array}{l}\mathrm{N}=84 \\
(58.7) \\
\\
\begin{aligned} 50(35.0) \\
13(9.1) \\
6(4.2) \\
15(10.5)\end{aligned}\end{array}$ & $\begin{array}{c}\mathrm{N}=136(100.0) \\
136(100.0) \\
0(0.0) \\
0(0.0) \\
112(82.4)\end{array}$ & $\begin{array}{c}\text { Likelihood-ration } \chi^{2} \\
=66.800 \\
(<0.001)\end{array}$ \\
\hline $\begin{array}{l}\text { *Most important reason for not always } \\
\text { wearing both gloves and coveralls while } \\
\text { working (for those not wearing it) } \\
\text {-Do not have regular access to PPEs } \\
\text {-Do not have time to wear them } \\
\text {-Can work safely without them } \\
\text {-Do not believe they are really protective } \\
\text {-Wearing them make it difficult for me to } \\
\text { do my work }\end{array}$ & $\begin{array}{l}=59(41.3) \\
\begin{array}{c}36(25.2) \\
3(2.1) \\
5(3.5) \\
2(1.4) \\
13(9.1)\end{array}\end{array}$ & $\begin{array}{c}\mathrm{N}=24(17.6) \\
12(8.8) \\
2(1.5) \\
7(5.1) \\
0(0.0) \\
3(2.2)\end{array}$ & $\begin{array}{c}\text { Likelihood-ration } \chi^{2} \\
\qquad \begin{array}{c}=7.374 \\
(\mathrm{P}=0.120)\end{array}\end{array}$ \\
\hline $\begin{array}{l}\text { Disposal of used needle and syringe } \\
\text { among doctors } \\
\text {-Discard both syringe and needle into the } \\
\text { safety box without recapping } \\
\text {-Recap needle and discard both syringe } \\
\text { and needle } \\
\text {-Disconnect and discard needle and } \\
\text { replace with new needle for another drug } \\
\text { administration on the same patient }\end{array}$ & $\begin{array}{l}52(36.4) \\
91(63.6) \\
0(0.0)\end{array}$ & $\begin{array}{l}58(42.7) \\
75(55.1) \\
3(2.2)\end{array}$ & $\begin{array}{l}4.697 \\
(0.096)\end{array}$ \\
\hline
\end{tabular}

studies in Nigeria where $62.1 \% 0^{10}$ and $95 \%{ }^{15}$ of the health workers believe that SP protects health workers from getting infections from patients. Studies have shown that HCWs are highly at risk of occupational hazards as they perform their clinical duties in the hospital especially when disposing bacteriological and other laboratory waste ${ }^{20}$. Only $12.6 \%$ of doctors and $19.1 \%$ of the MLSs reported knowledge of a hospital policy that enhances compliance to SP and this agrees with other reports ${ }^{14}$.

Concerning the resources available for practice of SP, our respondents reported lack of resources. Poor supply of PPE was reported in both groups. This is similar to findings in other studies in low income countries ${ }^{10,15}$. Concerning respiratory hygiene, only $36.8 \%$ of the MLSs and $25.9 \%$ of doctors reported that there were signs at entrances with instructions on cough etiquette however $21 \%$ of doctors and $17.6 \%$ of MLSs reported no measures were put in place. This has shown that there are inadequate signs in the hospital encouraging SP.

Concerning the practice of SP, there was a significant difference between the doctors and the MLSs. The MLSs were more likely to use PPEs than the Doctors regularly, this could be due the fact that majority of the MLSs $(73.5 \%)$ received training on wearing and removal of PPE compared to only $14.7 \%$ of the doctors. Lack of PPE was the major reason for non use among doctors.. The low use of PPE among doctors in this study is greatly lower than what was found among doctors in India, where glove use was found to be $85.1 \%{ }^{11}$. In contrast, only $2.5 \%$ of health workers in Ilorin wore protective aprons ${ }^{10}$.

Safe disposal of used needles and syringes was very poor. Recapping was still being practiced by of doctors and MLS. This is similar to what was found in India, where 59.3\% of doctors and nurses reported recapping of used needles ${ }^{11}$.More doctors practiced recapping than the MLSs similar to what Sadoh reported that recapping was more likely to be done by doctors than nurses or MLS $^{1}$. (Table 5)

The enablers to practice of SP among the two groups was mostly when managing an infected person, whereas the constraints were mostly non-availability of PPE, similar to findings in a study in North East Nigeria where $98.6 \%$ reported non compliance due to non-availability of equipment ${ }^{10}$. Poor commitment of hospital management towards provision of basic hospital amenities and personal protective devices have been reported in some studies as a barrier to practicing universal precautions ${ }^{21,15}$. Some respondents also found it difficult to use PPE during emergency situations. (Table 6) This is similar to some other studies where it was reported that during emergencies it was difficult to practice $\mathrm{SP}$ as well as during high job demands ${ }^{21}$. Both doctors and 
Table 6: Enablers, Constraits and Suggestions on measures to be put in place to enable workers comply with standard precautions

\begin{tabular}{|c|c|c|}
\hline & Doctors & Lab Scientists \\
\hline Variables & $\begin{array}{c}\text { Frequency } \\
\mathrm{N}=143(100.0 \%)\end{array}$ & $\begin{array}{l}\text { Frequency } \\
\mathrm{N}=136 \\
(100.0)\end{array}$ \\
\hline \multicolumn{3}{|l|}{ Enablers: Situations which make the worker comply with $S P$} \\
\hline If there is an epidemic & $29(20.3)$ & $27(19.9)$ \\
\hline If I am managing an infected person & $106(74.1)$ & $98(72.1)$ \\
\hline If there are policies to punish non compliance & $8(5.6)$ & $11(8.0)$ \\
\hline \multicolumn{3}{|c|}{$\chi^{2}=0.684 ;$ P value $=0.710$} \\
\hline \multicolumn{3}{|l|}{ Constraints: Conditions that make it difficult to comply with $S P$} \\
\hline In emergency situation & $63(44.1)$ & $54(39.7)$ \\
\hline If I do not understand how to observe SP & $7(4.9)$ & $6(4.4)$ \\
\hline If PPEs are not available & $67(46.9)$ & $68(50.0)$ \\
\hline If it reduces my job efficiency & $6(4.1)$ & $8(5.9)$ \\
\hline \multicolumn{3}{|c|}{$\chi^{2}=0.887 ;$ P Value $=0.828$} \\
\hline \multicolumn{3}{|l|}{ Suggestions on making health workers comply with SP } \\
\hline Facilities for hand hygiene should be regularly supplied & $120(83.9)$ & $13(9.6)$ \\
\hline Personal protective equipment should always be available & $143(100.0)$ & $27(19.9)$ \\
\hline Disinfectants and other resource for environmental cleaning should always be provided & $98(68.5)$ & $23(16.9)$ \\
\hline Regular training of workers on standard precautions & $104(72.7)$ & $50(36.8)$ \\
\hline Supportive supervision of workers to ensure compliance & $62(43.4)$ & $3(2.2)$ \\
\hline All above & $102(71.3)$ & $20(14.7)$ \\
\hline
\end{tabular}

Table 7: Association of occupation and exposure to patient's serum/use of PPEs/nosocomial infection

\begin{tabular}{|c|c|c|c|c|c|c|c|}
\hline \multirow[t]{2}{*}{ Variables } & \multicolumn{2}{|c|}{$\begin{array}{l}\text { Skin has been exposed to patient's serum } \\
\text { while working }\end{array}$} & \multicolumn{2}{|c|}{$\begin{array}{c}\text { Always wear PPEs (gloves or coveralls) } \\
\text { while working }\end{array}$} & \multicolumn{3}{|c|}{ Has developed nosocomial infection since starting work } \\
\hline & $\begin{array}{c}\text { Yes } \\
\mathrm{N}=206 \\
(\%)\end{array}$ & $\begin{array}{c}\text { No/Can't remember } \\
73 \\
\text { (\%) }\end{array}$ & $\begin{array}{c}\text { Yes } \\
\mathrm{N}=196 \\
(\%)\end{array}$ & $\begin{array}{c}\text { No } \\
\mathrm{N}=83 \\
(\%)\end{array}$ & $\begin{array}{c}\text { Yes } \\
(\%) \\
\mathrm{N}=48\end{array}$ & $\begin{array}{c}\text { No } \\
(\%) \\
\mathrm{N}=205\end{array}$ & $\begin{array}{l}\text { Do not know } \\
\qquad \begin{array}{c}\mathrm{N}=26 \\
(\%)\end{array}\end{array}$ \\
\hline $\begin{array}{l}\text { Doctor } \\
\text { Lab scientist }\end{array}$ & $\begin{array}{l}114(79.7) \\
92(67.6)\end{array}$ & $\begin{array}{l}29(20.3) \\
44(32.4)\end{array}$ & $\begin{array}{l}84(58.7) \\
112(82.4)\end{array}$ & $\begin{array}{l}59(41.3) \\
24(17.6)\end{array}$ & $\begin{array}{l}20(14.0) \\
28(20.6)\end{array}$ & $\begin{array}{l}110(76.9) \\
95(69.9)\end{array}$ & $\begin{array}{l}13(9.1) \\
13(9.5)\end{array}$ \\
\hline Lab scientist & & $\begin{array}{l}5.259 ; \\
0.022\end{array}$ & & & & $\begin{array}{l}\chi^{2}=2.133 \\
P=<0.144\end{array}$ & \\
\hline
\end{tabular}

MLSs have been exposed to serum during the course of their jobs. Exposure to blood and body fluids by health care workers is one of the major occupational hazards and this high level of exposure emphasizes the dire need for them to be educated on SP and the need for hospital policies to be enforced.(Table 7)

\section{Conclusion}

Doctors and MLSs have a good attitude to standard precautions but in depth knowledge and compliance is very poor. Hand hygiene, use of personal protective equipment and needle safety need to be re-emphasized. Training on standard precautions and use of personal protective equipment should be done more often and consistently. Standard precautions should be included in the curriculum of all health workers. Hospital policies should be enforced and management should provide materials needed for the practice of infection control.

\section{References}

1.Sadoh WE, Fawole AO, Sadoh AE, Oladimeji AO, Sotiloye OS. Practice of universal precautions among health care workers. J. Natl Med. Assoc. 2006; 98:722-6
2.Talashek ML, Kaponda CP, Jere DL, Kalulafula U. Mbeba MM, Mc Creary LL et al. Identifying what rural health workers in Malawi need to become HIV prevention leaders. J. Ass. Nurses AIDs care. 2007; 18: 41-50.

3.Isara AR, Ofili AN. Knowledge and practice of standard precautions among health workers in Federal medical centre, Asaba, Delta State, Nigeria. Niger Postgrad Med J. 2010; 17(3): 204-209.

4.Gerbending JL, Incidence and prevalence of HIV,HBV,HCV and cytomegalovirus amongst healthcare personnel at the risk of blood exposure. Final report from a longitudinal study. J Infect Dis. 1994; 170: $1410-1517$.

5.Chan E, Chan V, Ho B, Lai Cy et al. Nurses knowledge of and compliance with universal precautions in an acute care hospital. Int J. Nursing studies. 2002; 39: 157-63.

6.Center for Disease Control Update, Universal precautions for prevention of transmission of human immunodeficiency virus, hepatitis $\mathrm{B}$ virus and other blood borne pathogens in health care settings. MMWR. Morb Mortal weekly rep. 1988; 37 (24): 377-382, 87-88.

7. World Health Organization. The world health report. Box 4.4. 2002. Geneva, Switzerland. http://www.who.int/whr/2002/ chapter 4/en/ index $8 \mathrm{html}$. Accessed on 3rd September 2016.

8.Marcus R. Center for Disease Control. Co-perative needlestick 
surveillance group. Surveillance of health care workers exposed to blood from patients infected with human immunodeficiency virus. $\mathrm{N}$ Eng. J Med. 1988; 319: 118-1123.

9.Okechukwu EF, Modreshi C. Knowledge and practice of standard precautions in Public health facility in Abuja, Nigeria. Int Jf Infect Control. 2012; 8: 3.doi:10.3396/ijic. v8i3.022.12

10.Abdulraheem IS, Amodu MO, Saka MJ, Bolarinwa OA, Uthman MMB. Knowledge, Awareness and compliance with standard precautions among health workers in North Eastern Nigeria. J Community Med Health Educ. 2012; 2: 131. doi: 10.4172/jcmhe. 1000131.

11.Sangini P, Sumia N, Ranjitha SS. Health care workers and standard precautions: perceptions and determinants of compliance in the emergency and trauma triage of a tertiary care hospital in S. India. International Scholarly Research Notices, vol. 2014, Article ID 685072 , 5 pages, 2014. doi:10.1155/2014/685072.

12.Adinma ED, Ezeama C, Adinma JI, Asuzu MC. Knowledge and practice of universal precautions against blood borne pathogens amongst house officers and nurses in tertiary health institutions in Southeast Nigeria, Niger J. Clin. Pract. 2009; 12(4): 398-402.

13. Agu PU, Ogboi SJ, Ezugwu EC, Okeke TC, Aniebue PN. The knowledge, attitude and practice of Universal Precautions among rural primary health care workers in Enugu S.E. Nigeria. World Journal of Pharmacy and Pharmaceutical Sciences. 2015; 4(9): 109-125.

14. Amoran OE, Onwube OO. Infection control and practice of standard precautions among health care workers in Northern Nigeria. J Glob Infect Dis. 2013; 5(4): 156-163. doi:10.4103/0974-777X.122010.

15.Dimie O, Pondei K, Adetunji B, Chima G, Isichei C, Gidado S. Knowledge attitude and practice of Standard precaution of infection control by hospital workers in two tertiary hospitals in Nigeria. J Infect
Prev. 2015; 16(1): 16-22. doi 10.1177/1757177414558957.

16. Ofili AN, Asuzu MC and Okojie OH. Knowledge and Practice of Universal Precautions among nurses in central hospital, Benin City, Edo State, Nigeria. Niger Postgrad Med J. 2003 Mar; 10 (1): 26-31

17.Omuemu VO, Ogboghodo EO, Opene RA, Oriarewo P, Onibere O. Hand Hygiene practice among doctors in a tertiary health facility in Southern Nigeria. J Med Trop. 2013; 15: 96 -101doi:10.4103/22767096.123579 .

18. Tavolacci MP, Ladner J, Bailly L, Merle V, Pitrou I, Czernichow P. Prevention of nosocomial infections and standard precautions knowledge and source among health care students. Infect Control Hosp Epidemiol. 2008 Jul; 29(7): 642-7 doi: 10.1086/588683.

19. Amin TT, AL Noaim KI, Bu Saad MA, Turki Ahmed Al Maaalhm, Abdulaziz Al Mulhim, Marwah. Standard Precaution and Infection control, medical students knowledge and behavior at Saudi University. the need for change. Glob J Health Sci. 2013 July; J(4): 114-125. Doi: 10.5539/gjhs.v5n4p114.

20.Aiken LH, Sloane DM, Kloanski JL, Hospital nurses occupational exposure to blood. prospective, retrospective and institutional reports. Am J Public Health. 1997; 87: 103-7

21.Kio JO, Agbede CA, Ikponmwosa I. Analysis of compliance with universal precautions among staff and student nurses in Olabisi Onabanjo University Teaching Hospital. Journal of health, medicine and nursing. 2016; 26: 28-34 